\title{
PROSES KREATIF PENGARANG CHICKLIT DAN TEENLIT INDONESIA
}

\author{
Oleh: \\ Redyanto Noor \\ Jurusan Sastra Indonesia Fakultsa Ilmu Budaya Universitas Diponegoro \\ Jl. Prof. H. Soedarto, SH Tembalang Semarang 50275 \\ E-mail: redyanto_noor@yahoo.com
}

\begin{abstract}
An author creative process includes the issue of why and how the author wrote the novel. Among the chicklit and Teenlit novelists there are similar supporting factors, namely talent, hobby, intelligence, and daily life experience around them. The Supporting factors are then combined with skills, methods and storytelling which spontaneous and honest.They never thought about storytelling techniques when writing a novel. They do not think about the structure of fiction such as the grooves, figure-characterizations, backgrounds, storytelling, and so on.The creative process of the authors can not be separated from the influence of life in their surrounding environment that provides reality as a source of inspiration to write the story. The reality is in the form of social problems, personal problems, society, humanity, divinity, and so on. All sorts of information and experience are gained through association and access to information technology. All are quickly and simultaneously enrich the treasury of their knowledge so that they can talk anywhere, anytime, and about anything. Thus, the young chicklit and Teenlit novelists become successful and famous is not in a sudden and without a process. Nor because special facilities given by publisher or certain parties, but through hard work. Lot of terms and conditions that they can meet through their struggle.Thus, it can be concluded that the creative process of chicklit and Teenlit novelist is a blend of natural talent, hobby, intelligence, and life experience, supporting by intelligence, hard work, a wealth of experience, breadth of relationships, social sensitivity, the ability of storytelling and writing skills.
\end{abstract}

Keywords: creative process, inspiration source, hobby, experience, intelligence.

\section{PENDAHULUAN}

Artikel ini membahas proses kreatif pengarang novel chicklit dan teenlit Indonesia yang menulis dan menerbitkan karya-karyanya dalam kurun waktu lima tahun (2002-2007). Proses kreatif pengarang mencakup persoalan mengapa dan bagaimana pengarang menulis novel. Pengarang yang dimaksud adalah lima penulis chicklit dan teenlit Indonesia yang dikategorikan produktif, yakni menulis lebih dari 3 judul dalam kurun waktu lima tahun, yang salah satu novelnya mengalami cetak ulang lebih dari 5 kali dalam kurun waktu

lima tahun (2002-2007)

(http/www.gramedia.com: 12 Jun 2008).

Lima pengarang tersebut adalah Dyan Nuranindya (Dealova, April 2004 cetakan ke-1, November 2005 cetakan ke-8); Esti Kinasih (Fairish, Agustus 2004 cetakan ke1, September 2005 cetakan ke-10); Valeria Verawati (Nggak Usah Jaim Deh, Oktober 2005 cetakan ke-1, November 2006 cetakan ke-5); Gisantia Bestari (Cinta Adisty, Oktober 2004 cetakan ke-1, Desember 2005 cetakan ke-5); dan Maria Ardelia (Me versus High Heels! - Aku versus Sepatu Hak 
Tinggi!, Juni 2004 cetakan ke-1, Oktober 2005 cetakan ke-8).

Pembahasan proses kreatif pengarang tersebut mencakup profil dan proses kreatif mereka, yang berkaitan dengan latar belakang sosial pengarang, sumber inspirasi, motif, tujuan, dan strategi penulisan.

\section{PROFIL PENGARANG NOVEL CHICKLIT DAN TEENLIT INDONESIA}

Berikut ini akan dipaparkan profil lima pengarang novel chicklit dan teenlit Indonesia yang dikategorikan produktif, yakni menulis lebih dari 3 judul dalam kurun waktu lima tahun, yang salah satu novelnya mengalami cetak ulang lebih dari 5 kali dalam kurun waktu tersebut (2002-2007). Mereka adalah Dyan Nuranindya, Esti Kinasih, Gisantia Bestari, Valleria Verawati, dan Maria Ardelia.

Pengarang pertama adalah Dyan Nuranindya. Dyan Nuranindya lahir di Jakarta, 14 Desember 1985, anak bungsu dari dua bersaudara. Dalam kehidupan sehari-hari, ia lebih akrab disapa "Dichiel" (Dyan Kecil) oleh teman-temannya. Pada awalnya, ketika masih kecil, ia tidak pernah berpikir untuk menjadi penulis. Menurut pengakuannya, menulis merupakan salah satu bakat terpendam yang dimilikinya yang berhasil ia kembangkan (http/www. gramedia.com: 14 Jun 2008).

Selain menulis, Dyan Nuranindya juga aktif melakukan berbagai kegiatan, antara lain kesenian, pecinta alam, aktivis sosial, dan sebagainya. Sebagai pecinta alam ia telah mengunjungi berbagai tempat di wilayah Indonesia, terutama tempat-tempat yang terkenal memiliki keindahan eksotis dan mengagumkan. Semua pengalaman perjalanan itu dicatat dan didokumentasikannya dalam catatan perjalanan Indonesia, yang bertajuk “Aspirasi Jalan-jalan”, yang diunggah dalam situs pribadinya (http/www. dyannuranindya.com: 14 Juni 2008).
Di bidang sosial Dyan Nuranindya seringkali mengikuti berbagai kegiatan, misalnya seminar, lokakarya, workshop, serta anjangsana kemanusiaan dan pelestarian alam. Salah satu pengalaman paling mengesankan baginya adalah ketika menghadiri sidang E.C.O (Enviromental Children Organization) PBB tahun 2007. Ia terkesan oleh pidato seorang anak berusia 12 tahun yang mewakili anak-anak seluruh dunia, tentang kecemasan menghadapi masa depan dunia.

Isi pidato itu memberi kesadaran baru dalam dirinya tentang manusia dan alam yang semakin cepat mengalami proses kehancuran oleh ulah manusia. Oleh redaksi Gramedia Pustaka Utama Dyan Nuranindya dinilai sebagai salah satu penulis cerdas yang sering memunculkan pemikiran "ajaib" (unik dan kreatif). Ide-ide unik dan kreatif tersebut selain muncul dalam novel-novel yang ditulisnya, juga muncul pada artikelartikel yang dimuat di berbagai suratkabar dan majalah.

Dalam kurun waktu lima tahun (20022007) Dyan Nuranindya telah menulis tujuh judul novel. Empat judul di antaranya tergolong best-seller karena dicetak-ulang lebih dari 5 kali dalam kurun waktu lima tahun (2002-2007); dan tergolong sukses karena memperoleh rate-review (bintang rating) yang tinggi dari fans-community. Empat judul novel best-seller tersebut adalah Dealova (Gramedia Pustaka Utama, 2004), Rahasia Bintang (Gramedia Pustaka Utama, 2004), Canting Cantiq (Gramedia Pustaka Utama, 2005), dan Cinderella Rambut Pink (Gramedia Pustaka Utama, 2005).

Pengarang berikutnya adalah Esti Kinasih. Esti Kinasih lahir pada tanggal 9 September 1971 di Jakarta. Ia anak sulung dari tiga bersaudara. Mantan karyawan sebuah bank ini mengaku bahwa sebenarnya ia tidak sengaja menemukan jalan hidupnya sebagai penulis. Berawal dari hobinya sebagai pecinta alam, Esti Kinasih sering menyendiri untuk mencari ide dan inspirasi menulis. Karyanya yang pertama, Fairish, 
sudah memasuki cetakan ke-10 dalam kurun waktu dua tahun, dan telah disinetronkan oleh TV7 dalam tiga serial, yaitu Fairish Series, Fairish Making, dan Fairish Number (http//www.gramedia.com: 14 Okt 2008).

Dalam lampiran biodata penulis pada novel Fairish dicantumkan bahwa Esti Kinasih memiliki hobi koleksi perangko (filateli), koleksi T-shirt bergambar jeep, membaca, dan minum kopi (2005:303). Salah satu novel teenlit karya Esti Kinasih yang dianggap paling sukses adalah Fairish, yang penjualannya mencapai jumlah 100.000 eksemplar dalam kurun waktu satu tahun (2005). Selain menulis novel, Esti Kinasih juga aktif sebagai penulis freelance di berbagai majalah remaja nasional (http/www.gramedia.com: 14 Okt 2008).

Sampai akhir tahun 2006 ia telah menulis beberapa novel, di antaranya adalah Cewek!!! dan Still...', yang telah diterbitkan oleh Gramedia Pustaka Utama. Di luar kesibukannya menulis, ia juga menyukai petualangan menjelajah (avonturir) dan perjalanan pendakian (hiking). Petualangannya menjelajah lanskap alam seringkali dituangkannya dalam tema karya novel atau cerpennya. Bersama Dyan Nuranindya (penulis novel Dealova), Rachmania Arunita (penulis novel Eiffels... I'm in Love), Maria Ardelia (penulis novel Me versus High Heels! - Aku versus Sepatu Hak Tinggi!), Adithya Mulya (penulis novel Jomblo), ia merupakan salah satu pengarang remaja Indonesia paling fenomenal pada awal tahun 2000-an.

Dalam waktu lima tahun (2002-2007)

Esti Kinasih telah menerbitkan enam judul novel. Empat judul tergolong best-seller karena dicetak-ulang lebih 5 kali dalam kurun waktu lima tahun (2002-2007), dan tergolong sukses karena memeperoleh ratereview (bintang rating) yang tinggi dari fans-community. Empat judul novel bestseller tersebut adalah Fairish (Gramedia Pustaka Utama, 2004), Jingga dan Senja (Gramedia Pustaka Utama, 2005), Still (Gramedia Pustaka Utama, 2005), dan Cewek!!! (Gramedia Pustaka Utama, 2006).
Pengarang selanjutnya adalah Gisantia Bestari. Gisantia Bestari lahir di Jakarta 24 Januari 1991. Pertama kali menulis novel (Cinta Adisty) ketika duduk di kelas III SMP Sumbangsih 1 Jakarta Selatan. Menulis baginya kegiatan yang dilakukan dengan santai, kapan pun muncul ide cerita segera diketik di laptop. Ketika Ide macet segera ia matikan komputer dan mengerjakan kegiatan lain. Selain menulis, juga senang membaca. Pengarang yang dikaguminya adalah Mira W dan Eddy D. Iskandar, karena menurutnya ceritanya bagus (support@bukabuku.com, 14 Ags 2008).

Selama lima tahun (2002-2007) Gisantia Bestari telah menulis empat judul novel. Tiga judul di antaranya tergolong best-seller karena dicetak-ulang $\geq 5$ kali dalam kurun waktu lima tahun (2002-2007), dan tergolong sukses karena memeperoleh rate-review (bintang rating) yang tinggi dari fans-community. Tiga judul novel bestseller tersebut adalah Cinta Adisty (Gramedia Pustaka Utama, 2004), The Real Us (Gramedia Pustaka Utama, 2004),dan Backstreet Aja (Gramedia Pustaka Utama, 2005).

Pengarang lainnya adalah Valleria Verawati. Valleria Verawati lahir di Jakarta 2 Juni 1984. Ketika lahir orangtuanya memberi nama Verawati, setelah dibaptis namanya menjadi Valleria Verawati. Nama panggilan kesayangannya sehari-hari adalah Vera. Valleria Verawati menempuh pendidikan mulai Taman Kanak-kanak, Sekolah Dasar hingga SMP di Seraphine B.U. Jakarta, dan tamat SMA Vianney di Jakarta. Setelah meraih gelar Sarjana Psikologi dari Universitas Tarumanegara Jakarta, ia melanjutkan kuliah di Pascasarjana Universitas Tarumanegara Jakarta, Program Studi Magister Psikologi (http//www.gramedia.com:12 Mar 2008).

Selain memiliki hobi membaca dan menulis, Valleria Verawati juga memilki hobi mengoleksi novel Teenlit, khususnya Teenlit karya anak bangsa alias Teenlit asli Indonesia. Ia menganggap membaca karya dalam negeri lebih mudah memahaminya 
("nyambung") dibanding membaca karya asing. Meskipun begitu, ia sangat menyukai novel Harry Potter, karena Valleria Verawati sangat mengagumi J.K. Rowling (penulis novel Harry Potter.

Seperti halnya anak remaja lain yang seusia, Valleria Verawati sehari-hari, selain membaca dan menulis juga memiliki kegemaran melukis, jalan-jalan ke mal, "nongkrong”, "ngrumpi”, dan makan bareng "rame-rame". Ia mengaku sangat menikmati film horror, komedi, dan kisah romantis, serta mendengarkan musik pop melankolis.Gambaran tentang dirinya, kepribadian, kegemaran, dan obsesinya dapat ditafsirkan dari pengakuannya di situs http/www.valleriaverawati.com:

"Gw suka banget sama yang namanya doggy, apalagi kalo doggy kecil yang masih imut githu deh! Gw juga suka binatang lainnya, pokoknya yang lucu lah! I Love Pets. Gw orangnya kecil tapi lebih demen kalo disebut IMOET. Gw suka nulis, dan mimpi gw buat bidang nulis-menulis ini yah pengen buanget nulis buku yang bisa dibaca byk org and klo perlu jadi best seller githu. Bisa ga yah? Tapi sekarang novel karya gw udah beneran terbit loh! Jenisnya teenlit dan terbitan GPU. Judulnya "NGGAK USAH JAIM DES!”. Hua.... serasa senangnya... serasa dream comes true!

Gw juga suka baca. Gw punya koleksi teenlit di rumah, bahkan sekarang tuh buku2 gw sewain. Lumayan hasilnya bisa dipake lagi buat beli buku baru. Gw suka berteman sama sapa aja, asal orang itu juga bersedia nganggap gw temannya, dan gak pnya mksd terselubung ma gw. Gw orgnya juga rada tertutup neh, apa yang gw rasain lebih suka gw pendem sndr. Tapi gak selalu seh. Biasanya gw suka nulis ato corat-coret buat ngeluarin perasaan2 gw.Yang pasti, gw tuh tkng ngaret banget and plin-plan. Banyak tuh yg sering complain ma sifat gw yang satu itu. Tapi gimana lagi, da dari sananya sih!

And the last, gw mo banget punya banyak teman, karena menurut gw, org yg kaya itu adalah orang yang gak pernah merasa kesepian dalam hidupnya, saat dia sedang sendiri sekalipun”.
Selama kurun waktu lima tahun (20022007) Valleria Verawatitelah menulis empat judul novel. Tiga judul di antaranya tergolong best-seller karena dicetak-ulang lebih dari 5 kali dalam kurun waktu lima tahun (2002-2007), dan tergolong sukses karena memeperoleh rate-review (bintang rating) yang tinggi dari fans-community. Tiga judul novel best-seller tersebut adalah Nggak Usah Jaim Deh! (Gramedia Pustaka Utama, 2006), Pacarku Juniorku (Gramedia Pustaka Utama, 2006), Rahasia (Gramedia Pustaka Utama, 2007).

Terakhir adalah Maria Ardelia. Maria Ardelia lahir di Yogyakarta 7 November 1987. Ia merupakan anak sulung dari dua bersaudara, putri pasangan O. C. Harry Pudjiatmoko dan Benedicta Fronti Whinarsi. Setelah menamatkan SMA di St. Theresia Jakarta pada tahun 2005, Maria Ardelia melanjutkan pendidikan, kuliah di Fakultas Kedokteran Universitas Kristen Indonesia (UKI) Jakarta (www.mardelz@hotmail.com: 12 Mar 2008).

Dalam lampiran biodata penulis pada novel Me vs High Heels (Aku versus Sepatu Hak Tinggi!) tertulis bahwa Maria Ardelia memiliki hobi membaca, mendengarkan musik, dan menulis. Baginya, menulis merupakan panggilan hidup sehingga dalam keseharian, jika sudah menulis sering lupa waktu (2005: 351).

Selama lima tahun (2002-2007) Maria Ardelia hanya menulis satu judul novel, yaitu Me versus High Heels! (Aku vs Sepatu Hak Tinggi!) yang diterbitkan Gramedia Pustaka Utama (Juni 2004). Novel tersebut tergolong best-seller karena dicetak-ulang lebih dari 5 kali dalam kurun waktu empat tahun (2003-2007). Novel Me versus High Heels! (Aku vs Sepatu Hak Tinggi!) dianggap fenomenal di antara sekian banyak novel teenlit asli Indonesia karena frekuensi cetak-ulangnya tinggi, yakni 12 kali dalam waktu lima tahun. Interval cetak-ulang tidak dalam hitungan tahun tetapi dalam hitungan bulan. Diterbitkan pertama kali bulan Juni 
2004, cetak-ulang ke-empat bulan februari 2005, cetak-ulang ke-lima bulan Maret 2005, dan cetak-ulang ke-enam bulan Mei 2005 (lihat: Me versus High Heels! - Aku vs Sepatu Hak Tinggi!, 2004:iv).

\section{SUMBER INSPIRASI: DALAM CINTA, PERSAHABATAN, DAN PENGALAMAN HIDUP}

Dalam antologi The Creative Process, editor Brewster Ghiselin menyatakan bahwa "the creative process in the process of change...in the organization of subjective life", bahwa proses kreatif adalah proses perubahan...dalam organisasi kehidupan pribadi. Oleh sebab itu, menurut Budi Darma (Darma, 1984: 13) proses kreatif bersifat sangat personal sehingga tidak mungkin digantikan orang lain. Dapat dipastikan bahwa proses kreatif, antara seorang penulis dengan penulis yang lain tentu berbeda. Apabila ada persamaan, maka persamaan itu terbatas pada sumber inspirasi yang dapat berupa benda, pengalaman pribadi atau pengalaman orang lain, peristiwa, dan ide atau gagasan pokok.

Penggarapan tema yang sama oleh penulis yang berbeda akan melahirkan kisah yang berbeda, karena storage penulis yang satu berbeda dengan penulis lainnya. Latar belakang kehidupan penulis sangat berpengaruh terhadap proses kreatif yang dimilikinya. Mulai dari proses penemuan ide cerita, penyerapan inspirasi, pemilihan isu yang angkat diangkat, pesan yang disampaikan, kongkretisasi cerita, sampai pada teknik penulisannya.

Latar belakang kehidupan penulis yang dimaksud di atas adalah rentang perubahan fisik, psikis, sosial yang terjadi dan dialami secara empirik oleh penulis yang bersangkutan. Perubahan fisik mencakup pertumbuhan anatomi tubuh yang berpengaruh secara langsung terhadap kemampuan motorik. Perubahan psikis menyangkut perkembangan kejiwaan yang secara langsung berpengaruh terhadap kemampuan afektif dan sensorik; daya serap (absorbsi), daya cerna (analitis), daya nalar (kritis), dan daya ungkap (ekspresi).

Perubahan sosial menyangkut perkembangan interaksi dengan lingkungan menurut Hurlock (1980: 210-216) secara langsung berpengaruh terhadap kemampuan beradaptasi, berposisi, bersinergi, dan berkomunikasi dengan lingkungan. Seluruh perubahan tersebut secara akumulatif mengisi storage penulis yang mempengaruhi dan membentuk proses kreatifnya. Demikian pula dengan proses kreatif para penulis novel chicklit dan teenlit. Akumulasi kesan dan kenangan yang mereka peroleh sepanjang rentang usia membangun kolase (Damono, 2009:6) yang setiap saat berebut berdesakan meluap dalam bentuk ekspresi cerita.

Perubahan terus-menerus yang terjadi dalam kehidupan pribadi Dyan Nuranindya memberikan kontribusi bagi pematangan kreativitas yang dimilikinya sehingga ia meraih keberhasilan sebagai salah satu penulis novel teenlit terkemuka di Indonesia. Semula ia tidak pernah membayangkan menjadi penulis terkenal. Sejak masa kanakkanak hingga remaja ia mempunyai minat dan obsesi yang berubah-ubah sebagaimana remaja lain seusianya, yakni mengalami proses psikologis pencarian bentuk perkembangan kepribadian ke arah pematangan.

Faktor pembeda perkembangan seorang remaja dengan remaja lainnya adalah bentuk pengalaman psikologis yang mereka alami. Sebagaimana dikatakan Harlock (1980:171, 233) bahwa bentuk pengalaman psikologis tersebut cenderung dipengaruhi situasi eksternal yang dihadapi sehari-hari, yang memberi kesan kuat dan menantang emosi. Situasi eksternal yang dihadapi Dyan Nuranindya dalam kehidupan sehari-hari selama masa kanak-kanak hingga remaja setiap saat mengubah kondisi kejiwaannya, terutama dalam hal minat dan obsesinya.

Dari sekian banyak situasi eksternal tersebut terdapat situasi tertentu secara psikologis meninggalkan kesan kuat 
sehingga mendorong hasrat Dyan Nuranindya pada suatu minat dan obsesi tertentu sebagai sumber inspirasi. Minat dan obsesi Dyan Nuranindya menulis novel berawal dari kegemaran membaca dan menikmati buku-buku cerita. Dengan membaca dan menikmati buku-buku cerita ia merasa lepas dan bebas mengembarakan imajinasinya sesuka hati. Kegemaran membaca dan menikmati buku-buku cerita tersebut berkembang menjadi kekaguman, tidak saja pada isi cerita tetapi juga pada penulisnya.

Obsesi Dyan Nuranindya pada penulis idolanya sesuai dengan teori Hurlock (1980: 172, 234) memang mampu menumbuhkan hasrat identifikasi dan aktualisasi diri sebagaimana diri sosok yang diidolakan tersebut. Secara psikologis ia membandingkan diri (meniru, menyamakan diri) dengan seseorang yang diidolakan sebagai sebuah proses pencarian bentuk identifikasi dan aktualisasi diri. Dyan Nuranindya menulis novel karena didorong hasrat berbagi cerita dengan orang lain, berbagi pengalaman menghadapi persoalan hidup dan menemukan pemecahannya sehingga ia merasa telah memberikan manfaat bagi orang lain.

Semua berawal ketika saya membuka buku harian saya. Dari situ saya berpikir, ternyata saya, kamu, dia, dan mereka punya cerita masing-masing dalam kehidupan ini dan masing-masing punya cara sendiri untuk menyelesaikan masalah. Lalu kenapa kita nggak bertukar cerita? Kenapa banyak diantara kita yang terlalu egois nggak mau menceritakan bagaimana menyelesaikan, mencari, mendapat dan mempertahankan halhal yang kita raih kepada orang lain agar orang lain juga bisa maju, bisa berkembang?

Saya memang sengaja memajang foto penulis-penulis Indonesia yang memang saya kagumi (di samping masih banyak lagi penulis hebat lain yang saya baca dan kagumi karya-karya mereka yang tidak bisa saya pajang semua foto-fotonya disini.) karena saya menganggap mereka termasuk pahlawan yang membantu saya untuk berpikir lebih maju. Berpikir bagaimana saya bisa menuangkan ide, pikiran dan pendapat agar saya bisa share ke orang lain seperti yang telah mereka lakukan terhadap saya (dyannuranindya @yahoo.com: "My Wonderful Life”, 15 Okt. 2008).

Titik balik (turning-point) kehidupan Dyan Nuranindya yang menyebabkan ia mengambil keputusan menentukan pilihan menulis novel adalah sebuah peristiwa tidak terduga. Pertemuannya secara tidak sengaja dengan penulis idolanya yang bernama Teguh Esha serta-merta menumbuhkan kepercayaan diri sekaligus kesadaran baru tentang banyak hal: kebersahajaan, kepedulian, kemanusiaan, alam semesta, dan ketuhanan. Pengalaman spiritual tersebut mendorong semangat Dyan Nuranindya untuk terus menulis novel.

Keinginan berbagi pengalaman dengan orang lain tentang segala sesuatu yang ditulis dalam novel-novelnya membawa manfaat bagi orang banyak, terutama yang sesusia dengannya. Hobi Dyan Nuranindya sebagai pekerja seni, pecinta alam, dan aktivis sosial membuatnya kaya pengalaman jasmani dan rohani. Berbagai peristiwa luar biasa dalam kegiatan dan petualangannya menjadi sumber inspirasi penulisan novel-novelnya. Setiap kali selesai melakukan satu kegiatan atau perjalanan penjelajahan selalu ada pengalaman istimewa diperolehnya yang selalu dituangkan dalam cerita novelnovelnya.

Sikap, prinsip dan falsafah hidup, pengalaman lahir dan batin, interaksi sosial dikaitkan dengan ekspresi menulis novel dapat disimpulkan bahwa perubahan terusmenerus yang terjadi dalam kehidupan pribadi Dyan Nuranindya telah membentuk pola kreativitas dalam menulis novel. Minat dan obsesi yang berubah-ubah pada anak dan remaja menurut Hurlock (1980:159, 216) disebabkan oleh berbagai siatuasi dan pengalaman eksternal.

Dari sekian banyak dan aneka macam situasi dan pengalaman eksternal tersebut 
terdapat situasi-situasi tertentu yang secara psikologis meninggalkan kesan dan kenangan kuat sehingga mendorong hasrat anak dan remaja pada suatu minat dan obsesi tertentu. Minat dan obsesi Dyan Nuranindya menulis novel berawal dari kegemaran membaca dan menikmati buku-buku cerita. Dengan membaca dan menikmati bukubuku cerita ia memperoleh kebebasan mengembangkan imajinasinya.

Kegemaran membaca dan menikmati buku-buku cerita tersebut berkembang menjadi kekaguman terhadap berbagai cerita yang menakjubkan. Ketakjuban terhadap berbagai cerita itu berkembang menumbuhkan keterpesonaan terhadap penulisnya yang ia anggap sebagai orangorang luar biasa. Keterpesonaan Dyan Nuranindya pada penulis idolanya menumbuhkan keinginan mengidentifikasikan (menganggap diri sama) dan mengaktualisasikan (berlaku diri seperti) dirinya sebagaimana diri penulis yang diidolakan tersebut.

Ia menulis novel karena keinginan berbagi cerita, berbagi pengalaman dengan orang lain, sehingga ia merasa telah memberikan manfaat bagi orang lain. Pertemuannya dengan penulis-penulis terkenal yang dikaguminya memberi keyakinan mengambil keputusan, menentukan pilihan untuk terus dan mantap menulis novel. Sebab, pertemuan tersebut mampu menumbuhkan kepercayaan diri, sekaligus membuka kesadaran baru tentang makna hidup. Pengalaman spiritual tersebut menguatkan semangat Dyan Nuranindya menulis novel untuk berbagi pengalaman dengan orang lain, terutama dengan anakanak remaja seperti dirinya agar hidupnya menjadi lebih bermakna.

Penulis novel teenlit bernama Esti Kinasih pada awalnya tidak pernah membayangkan dirinya menjadi penulis novel terkenal. Sebagai karyawan sebuah bank ia sebenarnya telah mencapai kehidupan yang mapan secara ekonomi. Akan tetapi, rutinitas pekerjaan yang dilakukan setiap hari di tempat bekerja membuatnya jenuh dan frustrasi. Esti Kinasih merasa tidak memperoleh kepuasan batin, karena tidak dapat berbagi pengalaman dengan orang lain. Kesibukan sehari-hari berhitung dengan angka dan berhadapan dengan orang-orang (nasabah bank) yang sibuk berurusan dengan uang, dari pagi hingga petang, membuatnya kehilangan kesempatan berinteraksi dengan lingkungan luas. Di tengah kejenuhan dan frustrasi bekerja, Esti Kinasih merindukan masa-masa lalunya ketika masih menjadi mahasiswa. Sebagai pecinta alam, yang aktif menjelajah alam: mendaki gunung, menyusuri arung jeram, dan memanjat tebing, ia terbiasa hidup lepas di alam bebas, berinteraksi dengan alam dan lingkungan masyarakat (http/www.gramedia.com: 14 Okt 2008).

Mencermati latar belakang kehidupan Esti Kinasih tersebut dapat dirangkum empat hal berkenaan dengan proses kreatif yang dimilikinya, yakni mengapa dan bagaimana Esti Kinasih menulis novel: (1) motif menulis novel timbul karena dorongan keinginan menghibur orang lain, sekaligus berbagi pengalaman dengan orang lain; (2) keindahan alam dan keragaman lingkungan sosial menjadi sumber inspirasi yang tidak akan pernah habis digali sebagai bahan cerita yang akan ditulis; (3) menulis novel tidak ada bedanya dengan mengungkapkan gagasan sebagai respon, menyikapi pengalaman-pengalaman luar biasa (kebahagiaan, penderitaan, kesedihan, keharuan, kekecewaan, kemarahan) yang dihadapi dan dirasakan dalam kehidupan sehari-hari; (4) menulis novel tidak harus didasarkan pada kemampuan teknis yang bersifat teoretis. Kebiasaan membaca buku cerita mengasah ketrampilan menuliskan pikiran dan pengalaman dalam bentuk buku cerita.

Empat pernyataan tersebut secara akumulatif membentuk pola kreativitas Esti Kinasih dalam menulis novel. Perubahan terus-menerus yang mewarnai kehidupannya sejak masa kanak-kanak, masa remaja, hingga masa dewasa: gemar bermain 
semasa kanak-kanak dan remaja, menjadi aktivis mahasiswa, pecinta alam, karyawan bank, semua berperan membangun minat dan obsesinya. Minat dan obsesi Esti Kinasih menulis novel terbentuk dari kegemaran membaca dan menikmati bukubuku cerita. Dengan menulis novel ia merasa bebas mengekspresikan dirinya, bercerita kepada orang lain tentang banyak hal: cinta, kasih sayang, kepedulian, kemanusiaan, alam semesta, dan sebagainya. Keinginan bercerita tersebut secara terus-menerus memberi semangat Esti Kinasih sehingga ia tidak pernah kehabisan energi untuk menulis novel.

Gisantia Bestari gemar menulis sejak sejak kelas 2 Sekolah Dasar, baik dalam bentuk cerita pendek maupun puisi. Dalam lampiran biodata Gisantia Bestari pada novel Cinta Adisty (2004: 283) dituturkan bahwa pada mulanya ia menulis di lembaran kertas terpisah, apa pun ukurannya, sehingga seringkali tulisan-tulisan tersebut berserakan di mana-mana di dalam rumahnya. Cerita pendek yang ditulisnya pada lembar-lembar kertas tersebut selalu disertai ilustrasi sehingga kadang-kadang dapat dikategorikan sebagai komik.

Kebiasaan Gisantia Bestari menulis dengan bentuk berserakan semakin lama semakin mengarah ke bentuk buku. Dengan cara sederhana ia menjilid sendiri lembaranlembaran kertas HVS kosong ukuran A4 kurang lebih sepuluh halaman, dilipat menjadi dua. Dengan tulisan tangan ia mengisi lembar demi lembar kertas tersebut dengan cerita-cerita yang disusun berseri. Di sela-sela cerita tulisan tangan tersebut kadang-kadang ia menyisipkan tulisan berupa puisi. Tentu saja cerita pendek dan puisi yang ditulis Gisantia Bestari masih bersifat kekanak-kanakan, sebagaimana cerita dan puisi anak usia sekolah dasar.

Dalam lampiran biodata Gisantia Bestari pada novel Cinta Adisty (2004: 283284) dituliskan bahwa bakatnya yang luar biasa di bidang menulis sastra semakin terlihat jelas ketika salah satu puisinya yang berjudul "Burung" dimuat di majalah Bobo
No. 39/1999, pada saat ia berusia sembilan tahun dan duduk di bangku kelas 3 sekolah dasar. Peristiwatersebut menjadi titik balik perjalanan kepengarangan Gisantia Bestari. Kebanggaan luar biasa yang dirasakan Gisantia Bestari atas pemuatan puisi itu memicu timbulnya gairah dan semangatnya semakin giat menulis.

Setahun kemudian luapan gairah dan semangatnya menulis membuahkan hasil. Beberapa cerita pendeknya ("Kue Ulang Tahun”, "Tertukar Buku Cerita”, dan ”Juara Bintang Cilik") dimuat dalam rubrik "Taman Kecil” pada situs "Pinter", salah satu homepage yang dikelola Pacific Link. Dunia maya sebagai media komunikasi audio-visual futuristik memaksa Gisantia Bestari berusaha keras belajar komputer. Ia mulai mengumpulkan tulisan cerita pendek dan puisinya yang berserakan, diketiknya sendiri dengan komputer. Bahkan ia berusaha membuat desain cover untuk tulisan-tulisannya, termasuk cover novel best-sellernya Cinta Adisty. Di samping itu, keistimewaan lain novel Cinta Adisty adalah proses penulisannya, yakni diselesaikan dalam waktu dua minggu, ketika usia Gisantia Bestari genap tiga belas tahun kurang tujuh hari.

Dalam kehidupan sehari-hari salah satu kebiasaan yang berpengaruh besar terhadap proses kreatif Gisantia Bestari adalah menulis diary (catatan harian) dalam bentuk puisi. Kebiasaan tersebut dapat ditemukan dalam web-blog pribadinya, sebagaimana kutipan penggalan diarynya. Selain kebiasaan menulis diary di web-blog, Gisantia Bestari gemar interaktif dengan teman-temannya atau dengan siapa pun melalui berbagai situs pribadinya: e-mail, friendster, facebook maupun twitter. Dalam sehari ia dapat menghabiskan waktu berjamjam sekadar posting message atau chatting mengomentari persoalan apa saja. Mulai dari persoalan politik, ekonomi, olahraga, musik, sampai sekadar ngrumpi.

Bakat alamiah Gisantia Bestari menulis yang dimilikinya sejak kanak-kanak ternyata bersambut dengan kebiasaan yang 
ia lakukan dalam kehidupan sehari-hari. Kebiasaan berinteraksi dengan banyak orang, baik dalam pergaulan sehari-hari di sekolah, di kampus, di tempat "nongkrong”, maupun di dunia maya (e-mail, web-blog, friendster, facebook, twitter) membuat Gisantia Bestari trampil dan lincah bercerita. Ketrampilan dan kelincahan bercerita tersebut menjadi modal besar menulis novel.

Selain itu, kebiasaan berinteraksi dengan banyak orang juga membuat Gisantia Bestari memiliki banyak sekali teman: di sekolah, di kampus, di lingkungan pergaulan, dan di dunia maya. Intensitas interaksi tersebut memperkaya pengalaman batin memahami orang lain sehingga ia memiliki sifat setia kawan dan tenggang rasa yang tinggi. Gisantia Bestari selalu merasa dekat dengan orang-orang yang dikenalnya dengan baik, mulai dari anggota keluarganya, sahabat-sahabatnya di sekolah, di kampus, di lingkungan pergaulan, bahkan sampai teman-temannya di dunia maya.

Mencermati cara dan gaya Gisantia Bestari berinteraksi dengan sahabat dan teman-temannya di dunia maya dapat dikatakan bahwa ia sangat menikmati gaya dan suasana interaksi itu, apa pun bahan dan isi pembicaraannya. Ia menyatakan bahwa tidak ada keindahan lain di dalam hidupnya yang melebihi keindahan pertemanan atau persahabatan karena keindahan persahabatan tersebut menumbuhkan inspirasi bagi proses kreatifnya dalam menulis novel. Beberapa peristiwa penting yang berkesan dan meninggalkan kenangan yang pernah dialami menginspirasi penulisan novelnya.

Salah satu contoh adalah peristiwa kematian sahabatnya (sesama anggota Marching Band mahasiswa UI) bernama Achmad Rofie, membuatnya merasa sangat kehilangan. Puisi yang ditulis Gisantia Bestari dalam diary ("RIP") tentang kematian sahabatnya dapat ditafsirkan bahwa ia seakan-akan menemukan kesadaran baru tentang indahnya persahabatan, justru setelah ia kehilangan sahabatnya itu. Kesadaran tentang keindahan persahabatan itulah yang diungkapkan Gisantia Bestari dalam novel Cinta Adisty, sehingga ia merasa telah berbagi pengalaman dan kesadaran dengan orang lain.

Seperti halnya beberapa penulis novel chicklit dan teenlit lainnya, Gisantia Bestari juga tidak pernah memikirkan masalah teknis ketika menulis novel. Cerita mengalir dengan sendirinya seperti halnya apabila ia sedang bercerita kepada teman-temannya. Bahkan ia juga tidak pernah berpikir tentang tema cerita ketika hendak menulis novel, apalagi alur-pengaluran, latar-pelataran, tokoh-penokohan, pence-ritaan, dan sebagainya.

(http://gisantiabestari.tumblr.com: 15 Des 2008).

Tentang pengarang Valleria Verawatidalam lampiran biodata pada novel Nggak Usah Jaim, Deh! (2006: 243) disebutkan bahwa menulis novel sebenarnya bukan cita-citanya karena ia lebih tertarik menjadi seorang psikolog. Akan tetapi, kegemarannya mengoleksi novel teenlit mengubah arah keinginannya. Apalagi sejak masih duduk di bangku sekolah dasar ia sudah memiliki kegemaran menulis cerita. Cerita yang ditulis Valleria Verawati kebanyakan hanya ditempel di majalah dinding sekolah. Dalam lampiran biodata novel Nggak Usah Jaim Deh!, Valleria Verawati mengakui bahwa dengan menulis ia merasa bebas mengungkapkan seluruh perasaannya. Oleh karena itu, baginya menulis adalah salah satu cara menghibur diri yang menguntungkan. Selain bisa menyenangkan diri sendiri, barangkali juga bisa bermanfaat bagi orang lain, setidaktidaknya bisa memberikan hiburan atau sekadar memberikan kesibukan mengisi waktu luang.

Cita-citanya menjadi seorang psikolog membuat Valleria Verawati tertarik dan senang membaca buku-buku atau tulisantulisan lain seputar masalah kepribadian. Bahkan secara tidak ia sering memperhatikan sikap dan tingkah-laku orang-orang di sekelilingnya yang dianggapnya aneh atau unik. Kemudian selalu 
berpikir keras mencari jawaban, mengapa orang tersebut bersikap dan bertingkah-laku aneh. Apabila menemui jalan buntu, ia pun berandai-andai mendiagnosanya sendiri. Ternyata kebiasa-an tersebut berpengaruh besar terhadap proses kreatifnya dalam menulis. Novel Nggak Usah Jaim! memperlihatkan adanya persoalan-persoalan psikologis pada tokoh-tokohnya, terutama Nico. Tokoh yang dianggap memiliki persoalan kejiwaan, yaitu sifat hipokrit yang berlebihan, berusaha menutupi sifat buruknya dengan sikap dan tingkah-laku perfect (Verawaty, 2006: 92-94).

Selain masalah kejiwaan, Valleria Verawati juga tertarik mempelajari persoalan-persoalan sosial, yang membuatnya memiliki kepekaan sosial yang tinggi. Catatan-catatan yang tertulis dalam webblog pribadinya menunjukkan kepedulian sosial yang dimilikinya itu. Ia merasa sangat sedih dan prihatin memikirkan moral dan nurani sebagian bangsanya yang dinilainya semakin luntur: perlakuan terhadap manusia nyaris tidak ada bedanya dengan perlakuan terhadap hewan piaraan.

Perpaduan antara kepekaan dan kepedulian sosial dengan minat kepada persoalan kejiwaan membentuk pribadi Valleria Verawati sebagai sosok yang sentimental, mudah tersentuh dan terharu. Sebagaimana pengakuannya (Verawaty, 2006: 24) bahwa watak sentimental tersebut sangat mempengaruhi kebiasaannya menulis novel, seringkali sebelum menyatakan sesuatu ia selalu berpikir panjang. Jika sedang menulis cerita panjang ia sering dihinggapi kebosanan karena terlalu banyak perasaan yang harus ia ungkapkan. Dalam menulis novel Valleria Verawati tidak pernah berpikir tentang teknik bercerita. Semuanya dibiarkan mengalir apa adanya sampai suatu titik kebosanan datang, ia berhenti total, lalu mulai melanjutkan lagi ketika mood menulis muncul. Itulah sebabnya, penerbit Gramedia menyebutnya sebagai salah satu penulis novel teenlityang memerl ukan waktu lama untuk menyelesaikan satu novel.
Menulis novel bagi Maria Ardelia tidak cukup sekadar berbekal bakat. Ada beberapa syarat penting harus dimiliki seseorang yang akan menentukan pilihan untuk menulis novel. Yang utama adalah kemauan dan keyakinan kuat bahwa menulis novel akan memberikan manfaat. Tidak hanya bagi dirinya sendiri, tetapi juga bermanfaat bagi orang lain. Maria Ardelia menganggap bahwa sesungguhnya menulis adalah pekerjaan ketrampilan. Artinya, bahwa untuk memperolehnya harus dimulai dari niat dan rajin menulis terus-menerus. Oleh sebab itu, seperti yang dilakukan dan dialaminya, kegemaran membaca ternyata sangat membantu pekerjaannya menulis novel. Selain trampil menyusun cerita, juga tidak akan kehabisan bahan cerita menjadi kunci sukses menulis (www.mardelz@hotmail.com: 14 Maret 2007).

Tentang pengarang Maria Ardelia dicantumkan pada back-covernovel Me vs High Heels (2005: 351) bahwa Maria Ardelia memiliki hobi membaca, mendengarkan musik, dan menulis. Baginya menulis merupakan panggilan hidup sehingga dalam keseharian, jika sudah menulis sering lupa waktu. Lingkungan pergaulan di sekolah yang penuh romantika, tidak saja keceriaan dan kebahagiaan tetapi juga kesedihan dan keharuan, meninggalkan kesan dan kenangan tidak terlupakan. Semua kesan dan kenangan tersebut merupakan sumber inspirasi yang tidak pernah habis untuk dikisahkan dalam novelnya. Bahkan ketika mulai memasuki lingkungan pendidikan tinggi, yakni lingkungan kampus fakultas kedokteran UKI Jakarta, ia tetap menganggap peristiwa dan pengalaman sebagai sumber inspirasi kepengarangannya

(www.mardelz@hotmail.com: 2Jul 2007).

Seperti halnya penulis-penulis remaja lain yang sukses menulis novel teenlit, Maria Ardelia juga tidak memikirkan persoalan teknik bercerita ketika menulis novel. Ia sekadar bercerita dengan cara dan gayanya sendiri. Ia juga tidak peduli apakah cara dan 
gaya berceritanya mirip atau bahkan sama dengan penulis-penulis lain yang menjadi idolanya. Ia menganggap kemiripan atau kesamaan itu sebagai sesuatu yang wajar.

Gagasan cerita yang ditulis dalam novelnya juga bukan gagasan besar dan penting. Suatu ketika ia melihat seorang gadis remaja tampak "ribet" oleh sepatunya yang berhak tinggi. Lalu ia berpikir lucu saja: sepatu itu merampas kebebasan si gadis, ia tidak bisa menjadi dirinya sendiri. Dari situ lahir novel teenlit asli Indonesia yang dianggap fenomenal, yaitu Me versus High Heels! (Aku vs Sepatu Hak Tinggi!). Maria Ardelia berkomentar tentang novel karyanya tersebut, "Ceritanya, tuh, benerbener kayak beneran deh. Maksud gue kayak kehidupan kita-kita saja. Jayus lagi, kayak yang buat." ("Bikin Novel: Hobi yang Pantas Dilirik" wawancara Nina Setyawati dan Eka Alam Sari: Submitted by team epenulis Rabu 26 Sep 2007).

\section{PROSES PENULISAN: PADUAN BAKAT, HOBI, KECERDASAN, DAN KEHIDUPAN SEKELILING}

Sejak tahun 2003 novel remaja yang ditulis oleh pengarang remaja tampaknya sedang menjadi "tren”. Menurut Sitok Srengenge, pemilik penerbit KataKita, novel Nothing but Love (Laire Siwi, 2004) dicetak ulang dalam tempo sebulan. Sejak berdiri Maret 2004 sampai Februari 2006 penerbit KataKita telah menerbitkan enam judul novel. Yang paling laku adalah Nothing but Love, yang lain tidak laku, apalagi novel yang "serius-serius".

Fenomena kepopuleran novel karya pengarang-pengarang remaja semakin terbukti karena ada buku lain terbitan penerbit KataKita yang penjualannya seret, meskipun sudah diresensi dan didiskusikan di mana-mana. Penyebabnya adalah faktorcitra, orang seakan-akan takut berhadapan dengan sastra "serius" yang sulit. Selain itu, Sitok Srengenge mengatakan bahwa pengaruh pengarang perempuan sangat besar, terutama pengarang perempuan dari luar penulis chicklit dan teenlit yang sudah mempunyai nama besar. Nama pengarang akhirnya menjadi kartu garansi laku atau tidak lakunya sebuah novel.

Sitok Srengenge memaparkan bahwa penerbit KataKita menerbitkan karya pengarang yang sudah memperoleh sekitar tiga puluh penghargaan dengan desain cover buku sangat "ngepop", tetapi penjualannya macet. Penyebabnya adalah karena pengarangnya "cowok", umurnya sudah tua, lulusan ITB, sehingga karyanya dianggap serius, sulit, rumit. Padahal, ceritanya sangat "ngepop" dan cover-nya juga didesain "ngepop" ("Bikin Novel: Hobi yang Pantas Dilirik" wawancara Nina Setyawati dan Eka Alam Sari:Submitted by team e-penulis Rabu 26 Sep 2007).

Dibanding penerbit lain sebenarnya Gramedia Pustaka Utama telah lebih dahulu mencanangkan tema teenlit sejak kesuksesannya mengusung tema chicklit di tahun 2003, novel yang bercerita tentang kehidupan wanita kosmopolitan. Waktu itu ide chicklit muncul karena keinginan menerbitkan buku dengan meniru tema seperti di dunia mode. Menurut Listiana (editor senior Gramedia Pustaka Utama) istilahnya memang mengambil dari luar mengikuti jejak suksesnya novel Bridget Jones Diary karya Helen Fielding. Novel dengan tema apa pun yang ditulis oleh Helen Fielding dijamin laku keras sehingga pengarang didudukkan sebagai trade-mark penerbitan novel.

Kesuksesan tersebut menginspirasi Gramedia Pustaka Utama untuk menerbitkan tema lain yang juga diprediksi lebih menarik. Tahun 2004, Gramedia Pustaka Utama menentukan tema teenlit, dengan mengorbitkan nama dua pengarang remaja, yakni Dyan Nuranindya dan Maria Ardelia. Mengikuti jejak kesuksesan teenlit Gramedia Pustaka Utama, penerbit lain berlomba mencari cerita ringan dari pengarang remaja. Bahkan ada yang dibubuhi tulisan dan hologram pada cover yang berbunyi: Teenlit Asli Indonesia 
("Bikin Novel: Hobi yang Pantas Dilirik" wawancara Nina Setyawati dan Eka Alam Sari: Submitted by team e-penulis Rabu 26 Sep 200707).

Uraian di atas menunjukkan bahwa faktor utama pendukung keberhasilan penerbitan novel chicklit dan teenlitbukan tema atau pun kualitas cerita, tetapi lebih karena nama pengarangnya. Itulah sebabnya dapat dikatakan bahwa lima penulis novel teenlit asli Indonesia (Dyan Nuranindya, Esti Kinasih, Gisantia Bestari, Valleria Verawati, dan Maria Ardelia) dianggap sebagai representasi seluruh penulis novel teenlit asli Indonesia lainnya. Orientasi sebagian besar penulis dan juga pembaca novel teenlit tertuju kepada mereka berlima sehingga informasi apa pun tentang mereka selalu diburu-buru. Terbukti dari penuhsesaknya situs pribadi mereka oleh lalulalang "postingan" message dalam aneka ragam ekspresi. Aneka ragam ekspresi tersebut tertulis sekadar mengirim salam, bertanya ini-itu, memuji, memberi komentar, sampai pada "curhat" dan minta nasihat. Seluruh bentuk interaksi tersebut jika dirangkum maka akumulasinya adalah persoalan proses kreatif, yaitu mengapa dan bagaimana mereka menulis sehingga sukses menjadi pengarang terkenal.

Mencermati paparan proses kreatif lima penulis novel teenlit sebagaimana telah dipaparkan di awal dapat disimpulkan bahwa di antara mereka terdapat kesamaan faktor-faktor pendukung, yaitu bakat, hobi, kecerdasan, dan pengalaman hidup seharihari di sekeliling mereka. Faktor-faktor pendukung tersebut kemudian dipadukan dengan ketrampilan, cara dan gaya bercerita yang spontan dan jujur (serta-merta dan apa adanya) sehingga tercipta sebuah cerita yang disebut novel teenlit.

Analisis terhadap pengakuan lima penulis dan beberapa catatan khusus tentang mereka sebagaimana dipaparkan sebelumnya menunjukkan bahwa mereka memiliki kemampuan dan ketrampilan menulis cerita karena bakat alam. Terbukti bahwa tidak satu pun di antara mereka yang mengenyam pendidikan formal di bidang seni sastra. Bahkan sejak awal mereka tidak pernah membayangkan menjadi penulis novel yang sukses dan terkenal.

Meskipun pada umumnya mereka telah menggemari pekerjaan menulis sejak masa kanak-kanaktetapi tidak satu pun yang bercita-cita menjadi penulis novel. Dyan Nuranindya dan Valleria Verawati bercitacita menjadi seorang dokter dan psikolog, Gisantia Bestari menjadi ekonom, Maria Ardelia menjadi dokter. Bahkan Esti Kinasih telah menjadi ekonom yang bekerja di sebuah bank. Bakat alam yang mereka miliki terasah dengan baik karena didukung oleh salah satu hobi mereka yang sangat kuat, yaitu membaca. Kegemaran dan kebiasaan membaca sejak kecil secara teoretis mengasah ketrampilan menulis.

Sebagaimana telah dipaparkan di depan bahwa lima penulis tersebut genar sekali membaca. Sejak kanak-kanak aktivitas membaca tidak pernah lepas dari waktu mereka sehari-hari. Kegemaran membaca buku-buku itu menumbuhkan kekaguman mereka kepada pengarangpengarangnya. Dari kekaguman tumbuh keinginan mengidentifikasi diri seperti pengarang idolanya. Dari keinginan mengidentifikasi diri tumbuh niat dan tekad menyamai pengarang idolanya.

Niat dan tekad itu merupakan turningpoint (titik-balik) perubahan hidup mereka. Mereka menyebut peristiwa itu sebagai spiritual-moment dalam hidup sehingga citacita mencapai profesi tertentu dikalahkan oleh semangat menjadi penulis cerita. Jadi, ada turning-point moment yang mengubah arah perjalanan hidup mereka, yaitu saatsaat krusial menentukan pilihan. Bagi mereka menentukan pilihan hidup adalah persoalan paling sulit yang mesti dihadapi tetapi mereka berhasil melaluinya sehingga menjadi penulis novel chicklit dan teenlit.

Memperhatikan latar belakang keluarga dan pendidikan lima penulis chicklit dan teenlit tersebut sebagaimana telah dipaparkan di depan dapat diyakini 
bahwa mereka tergolong remaja-remaja pintar dan cerdas. Rata-rata mereka berasal dari keluarga mampu secara sekonomi. Terbukti dari ketersediaan fasilitas dan keterpenuhan kebutuhan hidup sehari-hari. Menghitung kebutuhan ekonomi memenuhi kegemaran dan kegiatan lima penulis itu tentu memerlukan biaya tidak sedikit.

Kegemaran membaca, "nonton", bermain musik, marching band, menjelajah alam, travelling adalah jenis-jenis kegemaran dan kegiatan yang tidak murah. Jenis-jenis kegemaran dan kegiatan itu juga tidak dapat dilakukan sembarang orang tanpa modal kemampuan pikiran yang lebih, yaitu kecerdasan. Apalagi jika mencermati lingkungan pendidikan yang mereka tempuh sejak kanak-kanak. SD Pangudi Luhur Jakarta, SMP Sumbangsih 1 dan SMP Theresia Jakarta, SMA Negeri VI Bulungan Jakarta dan SMA Negeri 70 Jakarta, Fakultas Ekonomi UI Depok, Fakultas Kedokteran UKI Jakarta, Fakultas Psikologi Universitas Tarumanegara Jakarta, adalah lingkungan pendidikan yang diimpikan kebanyakan anak dan remaja, tidak saja anak dan remaja di Jakarta, tetapi anak dan remaja di seluruh Indonesia. Keberadaan lima penulis itu di sekolah dan kampus tersebut meyakinkan bahwa mereka tergolong remaja yang cerdas.

Kecerdasan yang mereka miliki menjadi modal dasar dalam menulis cerita. Mengolah realitas sehari-hari yang "sepele" hingga menjadi cerita yang segar, lincah, dan menyenangkan tentu bukan pekerjaan mudah bagi anak remaja seusia mereka. Tanpa modal kecerdasan tidak mungkin Maria Ardelia mampu merangkai cerita sekreatif novel Me versus High Heels! (Aku vs Sepatu Hak Tinggi!). Dari peristiwa lucu tentang keribetan seorang gadis mengenakan sepatu hak tinggi dapat menjelma sebuah cerita sarat pemikiran dan gagasan: kebebasan, kemandirian, kebersahajaan, kepercayaan diri, kejujuran, jati diri, dan bangga menjadi diri sendiri. Yang dilakukan Maria Ardelia tersebut jelas menunjukkan bahwa ia remaja yang cerdas.

\section{PENUTUP}

Proses kreatif lima penulis tersebut tidak dapat dilepaskan dari pengaruh kehidupan lingkungan di sekelilingnya yang menyediakan realitas sebagai sumber inspirasi menulis cerita. Realitas itu berupa problem sosial, problem pribadi, pergaulan, kemanusiaan, ketuhanan, dan sebagainya. Semua adalah bahan inspirasi cerita yang dapat mereka olah dengan kecerdasan yang mereka miliki. Segala macam informasi dan pengalaman mereka peroleh melalui pergaulan dan akses terhadap fasilitas teknologi informasi (Information Technology) seperti internet-network, notebook, blackberry, iPhone, iPad, flashModem, dan sebagainya. Semua secara cepat dan berbarengan memperkaya perbendaharaan pengetahuan mereka sehingga mereka dapat berbicara di mana saja, kapan saja, dan tentang apa saja.

Wilayah-wilayah yang menjadi spaceicon anak remaja modern seperi kampus, mal, shopping-center, sport-center, foodcourt, cafe, distro (distribution-order), boutique, "pensi" (pentas seni) sekolah adalah tempat mereka beraktualisasi dan berekspresi. Tempat-tempat semacam itudominan mewarnai cerita-cerita mereka karena di wilayah-wilayah tersebut mereka merasa menjadi dirinya sendiri. Jadi, dalam menulis novel sesungguhnya mereka sedang bercerita tentang dirinya sendiri. Kesan kuat membaca novel-novel mereka adalah spontanitas. Ekspresi "ngobrol”, “curhat”, dan "ngrumpi" yang akrab, terbuka, dan apa adanya sebagaimana yang dilakukan seharihari memberi warna ekspresi penyajian cerita dalam novel mereka.

Mereka bercerita dengan jujur dan spontan karena tidak pernah memikirkan teknik bercerita ketika menulis novel. Mereka tidak memikirkan perangkat struktur cerita fiksi seperti alur-pengaluran, tokohpe_nokohan, latar-pelataran, pence-ritaan, dan sebagainya. Bahkan tema ceritanya pun tidak terpikirkan sebelumnya. Bagi mereka 
yang penting adalah bercerita apa adanya sesuai dengan keinginannya, dengan cara dan gaya mereka sendiri agar akrab dan mudah dipahami pembacanya.

Analisis di atas menunjukkan bahwa para remaja penulis novel chicklit dan teenlit tersebut menjadi penulis novel sukses dan terkenal tidak berlangsung tiba-tiba dan tanpa proses. Tidak pula karena fasilitas khusus yang diberikan penerbit atau pihak tertentu, tetapi melalui kerja keras. Banyak syarat dan ketentuan yang dapat mereka penuhi melalui perjuangan. Jadi, dapat disimpulkan bahwa proses kreatif penngarang novel chicklit dan teenlit adalah perpaduan dari bakat alam, hobi, kecerdasan, dan pengalaman hidup, didukung oleh modal kecerdasan, kerja keras, kekayaan pengalaman, keluasan pergaulan, kepekaan sosial, kemampuan bercerita, dan ketrampilan menulis.

\section{DAFTAR PUSTAKA}

Ardelia, Maria. 2005. Me Versus High Heels! Aku vs Sepatu Hak Tinggi (cetakan ke-5). Jakarta: Gramedia Pustaka Utama.

Bestari, Gisantia. 2005. Cinta Adisty (cetakan ke-12). Jakarta: Gramedia Pustaka Utama.

Chandra, Benny. 2004. "Chick Lit, Teen Lit, Lad Lit”. http//bennychandra.com/ 2004/08/07/chicklit-teenlit-ladlit/.

Hidup Kita”
http//bennychandra.com/
2005/04/13/ chicklit-teenlit-ladlit/.

Chaney, David. 2004. Lifestyle: Sebuah $\begin{array}{lr}\text { Pengantar } & \text { Komprehensif } \\ \text { (diindonesiakan } & \text { Nuraeni). } \\ \text { Yogyakarta: Jalasutra. } & \end{array}$

Damhuri, Elba. 2005. "Selisik: Teenlit" dalam Republika, Minggu 17 April 2005.

Damono, Sapardi Djoko. 2009. Sosiologi Sastra: Pengantar Ringkas. Jakarta: Editum.

2010. Kebudayaan Populer (di Sekitar) Kita. Jakarta: Editum.

Darma, Budi. 1984. Sejumlah Esei Sastra. Jakarta: Karya Unipress.
Dewi, Eriyanti Nurmala. 2005. "Sastra Chicklit, Sastra Kaum Perempuan Urban” dalam Pikiran Rakyat, 29 Januari 2005.

Eneste, Pamusuk (ed.). 1983. Proses Kreatif I. Jakarta: Gramedia.

Escarpit. Robert. 2005. Sosiologi Sastra (diindonesiakan Ida Sundari Hussein). Depok: Lembaga Penelitian dan Pengembangan, FPIB - Universitas Indonesia.

Hurlock, Elizabeth B. 1991. Psikologi Perkembangan: Suatu Pendekatan Sepanjang Rentang Kehidupan (diindonesiakan Istiwidiyanti \& Soedjarwo). Jakarta: Erlangga.

Ibrahim, Idi Subandi (ed.). 2003. Lifestyle Ecstacy: Kebudayaan Pop dalam Masyarakat Komoditas Indonesia. Yogyakarta: Jalasutra.

Kinasih, Esti. 2005. Fairish (cetakan ke-5). Jakarta: Gramedia Pustaka Utama.

Mg07. 2005. "Chicklit, dan Ritual Perempuan Kota” Republika, Minggu 16 Januari 2005. (http//www.republika.co.id/koran_ detail.asp?id=184097\&kat_id=305) 
Nuranindya, Dyan. 2006. Dealova (cetakan ke-13). Jakarta: Gramedia Pustaka Utama.

Razdan, Anjula. 2004. "Deconstructing Chicklit” Utne Magazine, Published April 26, 2004

Rey, J. (2002). More than Just The Blues: Understanding Serious Teenage Problems. Sydney: Simon \& Schuster.

Ruz. 2005. “Teenlit, Apa Sih Istimewanya?” dalam Republika, Minggu 6 Februari 2005.

Taufiqurrohman, Muhammad. 2010. "Produksi Budaya/Budaya Produksi Chicklit Indonesia di Penerbit Gagasmedia” Tesis Magister Program Studi Kajian Budaya, Fakultas Ilmu Pengetahuan Budaya, Universitas Indonesia, Depok.

Triwikromo, Triyanto. 2005. "Chicklit atau Teenlit: Bukan Sastra Remehtemeh” (tidak dipublikasikan) catatan pengalaman menyunting novel Teenlit Nothing but Love (Semata Cinta) karya Laire Siwi Mentari, penerbit Kata Kita.

Verawaty, Valleria. 2006. Nggak Usah Jaim Deh! (cetakan ke-6). Jakarta: Gramedia Pustaka Utama.

\section{Pustaka Media Sosial}

dyannuranindya@yahoo.com: ”My

Wonderful Life”, 15 Okt. 2008

http/www. dyannuranindya.com: 14 Juni 2008

http://gisantiabestari.tumblr.com: 15 Des 2008

http://gisantiabestari.tumblr.com: 15 Des 2008

http//www.gramedia.com:12 Mar 2008

http/www.gramedia.com: 12 Jun 2008

http/www. gramedia.com: 14 Jun 2008

http//www.gramedia.com: 14 Okt 2008

http/www.valleriaverawati.com

support@bukabuku.com, 14 Ags 2008

www.mardelz@hotmail.com: 2Jul 2007

www.mardelz@hotmail.com: 12Mar 2008 